\title{
Towards quantifying rate of scour using the Erodibility Index Method: case study
}

\author{
A.J. Rock \\ Simplot Grower Solutions, Wray, Colorado, U.S.A. \\ G.W. Annandale \\ Consultant, Highlands Ranch, Colorado, U.S.A.
}

J.D. Higgins

Colorado School of Mines Department of Geological Engineering, Golden, Colorado, U.S.A.

\begin{abstract}
This case study presents relationships between total energy input to plunge pools and scour depth at three BC Hydro dams in British Columbia, Canada. Total energy is defined as the product of stream power and time. The relationship indicates the potential to develop a technique quantifying the rate of scour of rock using the Erodibility Index Method (Annandale 1995; 2006).
\end{abstract}

The scour assessment used the Erodibility Index Method to theoretically quantify scour extent and compare it to observed scour. The Erodibility Index is quantified using in-situ rock parameters including UCS, RQD, joint spacing, aperture, alteration, roughness, and orientation. A graph relating the Erodibility Index and threshold stream power (Annandale 1995) is then used to quantify the ability of the rock to resist the stream power of flowing water. The stream power of the flowing water was quantified using daily discharge records and dam spillway geometries for flip-bucket jets.

Numerically generated scour profiles were used to quantify total energy at the surface of the plunge pool and at depth over time. The total energy input was then correlated with both the modeled and surveyed plunge pool depth to develop the relationship.

The study showed a statistically significant semi-logarithmic relationship between both modeled and surveyed scour depth and total energy input. In both cases, the rate of plunge pool development decreases over time, and continued energy inputs are required to enact changes to depth.

The study revealed that correlations between calculated and observed scour profiles improved with the quality of geologic information and the certainty by which jet stream power and its decay could be quantified. The geologic information at one of the sites was incomplete and resulted in poor comparisons between observed and calculated scour. At the other two sites, where geologic information was more complete comparisons were more favorable.

\section{INTRODUCTION}

Rock scour downstream of dam foundations and spillways is a significant dam safety concern. As design floods increase and older infrastructure is modified to pass larger amounts of water, downstream river beds and plunge pools are subjected to progressively larger stream power. Excessive scour due to plunging jets or high velocity flow in plunge pools, specifically, can undermine foundations, compromise the stability of riverbanks, and lead to eventual catastrophic dam failure. Traditionally most of the geological investigation of dam sites is focused on the dam foundation, abutments, and the upstream reservoir area. Experience has shown that the investigation of scour potential downstream of dam spillways is very important; rock quality in this area can have a significant impact on long term dam stability. Understanding the science of energy dissipation in both the atmosphere and the plunge pool can help more accurately predict scour and aid in the selection of the most effective energy dissipaters and rock reinforcement during spillway design.

This case study presents relationships between total energy input to plunge pools and scour depth at three BC Hydro dams in British Columbia, Canada using Annandale's Erodibility Index Method (EIM) (1995, 2006) for estimating rock scour depth in plunge pools. Modeled and surveyed plunge pool scour at the three dams are compared to the calculated cumulative energy consumed at the rock-water interface. The analysis accounts for geologic variability within the plunge pools, scour along twodimensional profiles, progressive plunge pool scour from a series of discharge events, and applies Ervine \& Falvey's (1987), Bollaert's (2002), and Castillo's (2006) research on fluctuating and mean dynamic 
pressure coefficients to calculate energy decay within the plunge pools.

In engineering practice, detailed geologic data are not always available. The dam sites assessed in this study represent different types of geologic environments, with different levels of geologic data density. The variety in data density at the dam sites is discussed to provide some insight into the influence of the amount of available geologic information on the accuracy of the results.

\section{BACKGROUND}

To assess plunge pool scour, both the erosive capacity of the water and the erosive resistance of the rock material must be quantified. The erosive capacity of the water can be represented by the rate of energy dissipation of the plunging jet over the jet impact area, also known as the applied stream power of the jet. Similarly, the resistance of the rock material to erosion can be represented by the amount of stream power that the material is capable of resisting over the applied area, calculated using Annandale's EIM.

\subsection{Erosive capacity of water}

The erosive capacity of plunging jets depends on the characteristics of the free falling jet (quantified based on Bollaert 2002; Ervine \& Falvey 1987; and Pfister et al. 2014) and the characteristic energy dissipation within the plunge pool (quantified based on Castillo 2006, 2007; Bollaert 2002). Jet trajectory and degree of breakup vary depending on the type of jet and spillway structure. All plunging jets in this analysis are rectangular in nature and issue from flipbucket structures.

Characterizing the airborne portion of the jet requires knowledge of the initial flow over the spillway and the amount of dispersion that occurs during the fall. The issuance velocity can be deduced from spillway discharge measurements and specific energy concepts (Henderson, 1966). The turbulence of the free falling jet entrains air. The degree of internal turbulence experienced by the plunging jet is a function of the jet issuance conditions and is represented by the initial turbulence intensity, Tu (Ervine \& Falvey, 1987; Ervine et al., 1997). Ski jump and flipbucket jets experience mixing during both flow down the spillway face and while airborne, which results in greater turbulence intensities. All three of the BC Hydro dam spillways assessed here consist of flip bucket type energy dissipaters.

The plunging jet geometry is also dependent on the issuance velocity, issuance jet thickness, average issuance angle, and Froude Number at the terminal structure. Jet breakup lengths for the flip-bucket type spillways were best represented by Pfister's (2014) relationships for rectangular jets.

Further energy dissipation occurs when the falling jet impacts the relatively stationary plunge pool. Ervine \& Falvey's (1987), Bollaert's (2002), and Castillo's (2006) research show that in an open, flat bottomed plunge pool the pressure component can be broken down into the mean pressure and the dynamic fluctuating pressure. The mean pressure represents the relatively constant pressure experienced in the plunge pool and the dynamic fluctuating pressure represents the amplitude of the pressure changes about the mean over time. Coefficients have been developed by the researchers to represent the portion of the total pressure at the plunge pool surface that exists at a given depth. The two coefficients include the average dynamic pressure coefficient, $\mathrm{C}_{\mathrm{p}}$, and the fluctuating dynamic pressure coefficient, $\mathrm{C}^{\prime}{ }_{\mathrm{p}}$.

Horizontal energy dissipation occurs as the frayed fringes of the jet mix with the stationary water of the plunge pool. Additionally, wall jets that develop at the rock-water interface transfer energy laterally outward at the contact with the plunge pool bottom. Bollaert (2002) addressed the issue of horizontal energy dissipation by developing radial decay coefficients that represent the proportion of the total pressure at a given depth that is available a distance $r$ radially outward from the jet centerline.

\subsection{Erosive resistance of earth material}

Annandale's EIM (1995) determined that the erodibility of earth materials was dependent on the material strength, block or particle size, discontinuity conditions and orientations, as outlined in Equation 1. Here $\mathrm{K}$ is the Erodibility index (EI) value, $\mathrm{M}_{\mathrm{s}}$ is the mass strength number, $K_{b}$ is the block size number, $K_{d}$ is the discontinuity/bond shear strength number, and $\mathrm{J}_{\mathrm{s}}$ is the relative ground structure number, as defined by Annandale (1995, 2006).

$K=M_{s} \cdot K_{b} \cdot K_{d} \cdot J_{s}$

Figure 1 shows the distribution of the data from Annandale's (1995) analysis and the derived scour threshold for various stream powers. The threshold stream power necessary to initiate erosion is related to the $\mathrm{EI}(\mathrm{K})$ value, with unitless $\mathrm{K}$ along the $\mathrm{x}$-axis and the associated stream power (in $\mathrm{kW} / \mathrm{m}^{2}$ ) along the y-axis. The dashed line represents the threshold value, separating cases where erosion occurred from cases where it did not. The threshold stream power necessary to initiate erosion $(\mathrm{Pc})$ is related to $\mathrm{K}$ as shown in Equations 2 and 3 (Annandale, 1995, 2006):

$$
\begin{aligned}
& P_{c}=0.48(K)^{0.44} \quad \text { for } K \leq 0.1 \\
& P_{c}=K^{0.75} \quad \text { for } K>0.1
\end{aligned}
$$




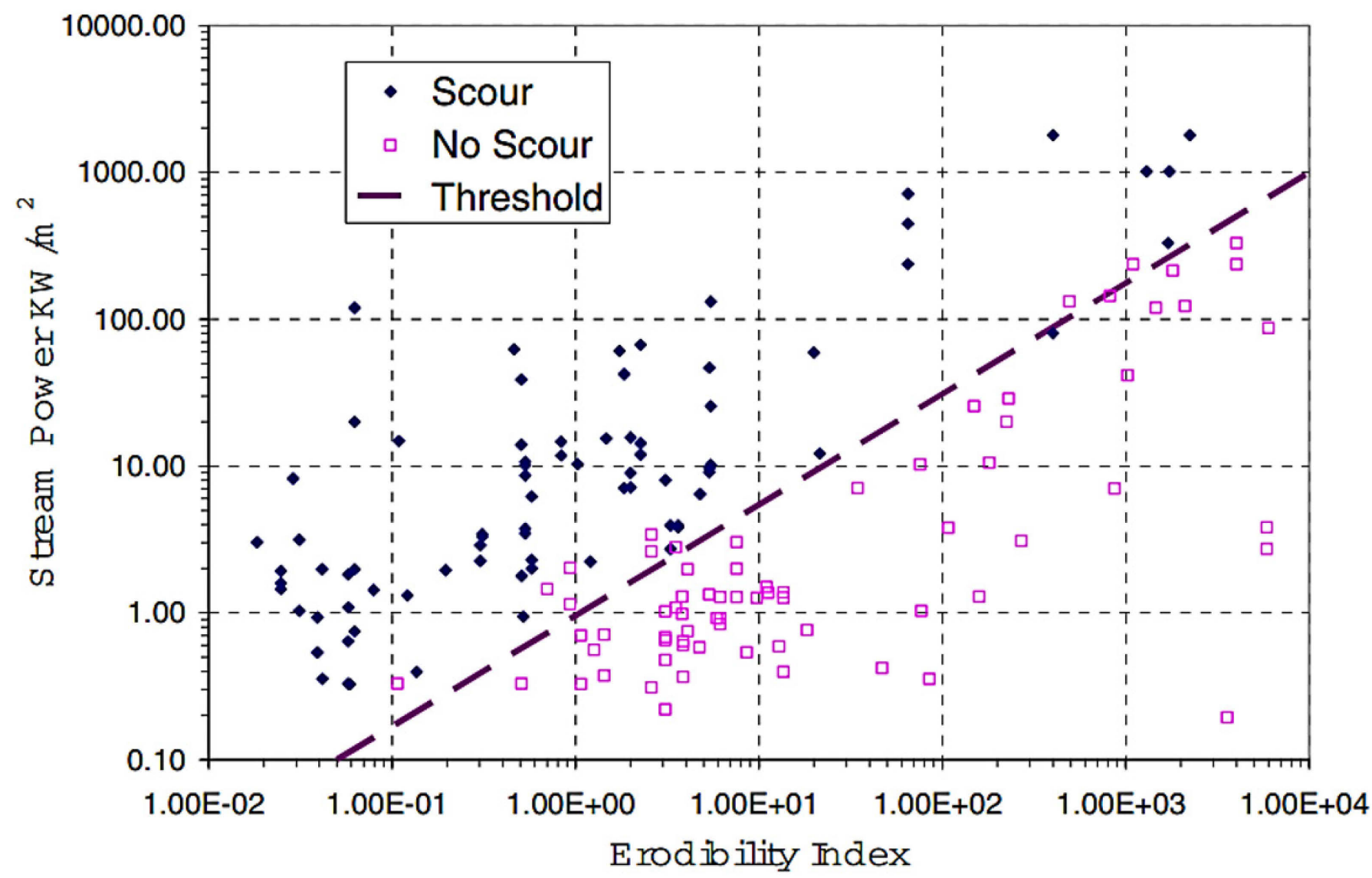

Figure 1. Erosion threshold relating stream power and Erodibility Index (Annandale 1995, 2006).

\section{DAM SITES}

Three dam sites were selected for this analysis, based on the availability of data to both a) characterize plunge pool materials and spillway discharge and b) validate modeling based on existing plunge pool surveys. The three sites include Peace Canyon Dam, Seven Mile Dam, and W.A.C. Bennett Dam; all sites are located within British Columbia and are owned and operated by $\mathrm{BC}$ Hydro, public energy utility.

Peace Canyon (PCN) and W.A.C. Bennett (WAC) Dams are located in north-central $\mathrm{BC}$ on the Peace River. The geologic environment here consists of flat-lying, continuous, sedimentary strata dominantly of sandstone, shale, and siltstone. Geologic information from the two sites indicates a general increase in rock erosive resistance with depth. With the exception of a more highly fractured 'hinge zone' that transects the PCN plunge pool, no major structural features are located within the area of interest. Both sites contain flip-bucket type spillway structures. The PCN spillway is a six-bay overflow spillway located at the approximate tailwater level. The WAC spillway is an overflow spillway with a long chute that discharges at a spoon-shaped flip structure located approximately $76 \mathrm{~m}$ above the tailwater level. Two profiles were selected for modeling at the PCN site: one downstream of spillway bays three and four and a second downstream of spillway bays five and six. One profile was selected for modeling at the WAC site, projecting out at a right angle from the terminal structure through the deepest surveyed portion of the plunge pool.

Seven Mile Dam (SEV) is located in southern BC on the Pend d'Oreille River near the US-Canada border. The geology at this location consists of a tilted complex metamorphic environment with a wide range of materials of varying erosive resistance. No mapping was conducted within the plunge pool, so the spatial distribution of the materials is unknown. The SEV spillway consists of a five-bay overflow spillway with a flip-bucket located approximately $9 \mathrm{~m}$ above the tailwater level. The model profile for this dam site is located downstream of spillway bays one and two.

\section{ANALYSIS}

After cross section locations were identified, the analysis for each site consisted of five parts: (1) geomechanical model creation; (2) Erodibility Index calculations; (3) hydraulic characterization; (4) scour assessment with numeric model; and (5) comparison of cumulative energy to modeled and surveyed depth results.

\subsection{Geomechanical model creation}

Geomechanical characterization of the dam sites was largely based on borehole data, geologic data from 
geologic investigation and design reports, foundation and abutment geologic maps, and regional geologic maps. Engineering geologic (EG) zones were identified for rock with similar engineering characteristics, including UCS, RQD, number of joint sets, joint roughness and alteration, and joint set orientation. Higher density geologic data naturally led to greater subdivision of materials into EG zones.

\subsection{Erodibility Index calculation}

The geomechanical characteristics of each zone and Annandale's EIM were used to assess the threshold stream power for each zone, based on Equation 1. EI values were assessed based on average rock parameters across an EG zone. To account for radial flow away from the jet at the rock-water interface, $\mathrm{J}_{\mathrm{s}}$ was calculated considering flow in the upstream as well as downstream direction and the minimum value was selected for use in the model.

The critical stream power values and initial plunge pool bathymetry were then used to create a $300 \mathrm{~mm}$ by $300 \mathrm{~mm}$ array along each plunge pool profile. Each array cell was assigned a $\mathrm{K}$ value based on the EG zone in which the cell was located. Cells located above the rock surface were assigned a $\mathrm{K}$ value of zero.

\subsection{Hydraulic characterization}

Daily spillway discharge and reservoir elevation data, provided by BC Hydro, were used with spillway rating curves to estimate gate height at the spillway crest for each day of recorded discharge at each site.
The flow characteristics at the crest were then used with the US Bureau of Reclamation's PROFILE Water Surface Profile Program for Prismatic Channels Version 1.10 (not dated) to estimate flow characteristics at the downstream end of the spillway. PROFILE is based on calculations and programming from the Bureau of Reclamation's Engineering Monograph No. 42 (Falvey, 1990) and uses the Standard Step Method to compute the supercritical water surface profile for a user-defined channel shape and slope. Flow characteristics calculated by PROFILE were based on simplified spillway profiles for each dam site.

\subsection{Numerical scour assessment}

The developed numerical model approximates the location of jet impact with the plunge pool and the energy dissipation that occurs with depth as the submerged jet moves through the water. Figure 2 shows the simplified numeric model workflow. The model uses the velocity and flow depth at the spillway terminal structure and the tailwater elevation to calculate the jet trajectory, point of impingement with the tailwater surface, turbulence intensity, break-up length and diameter of the jet at impingement. The stream power of the jet at plunge pool impingement is calculated based on the total discharge from the spillway gates, the jet footprint at impingement, and the elevation difference between the issuance Energy Grade Line and tailwater elevations

\section{\begin{tabular}{|l|l|l|}
\hline Free Falling Jet & Plunge Pool & Rock Mass \\
\hline
\end{tabular}}

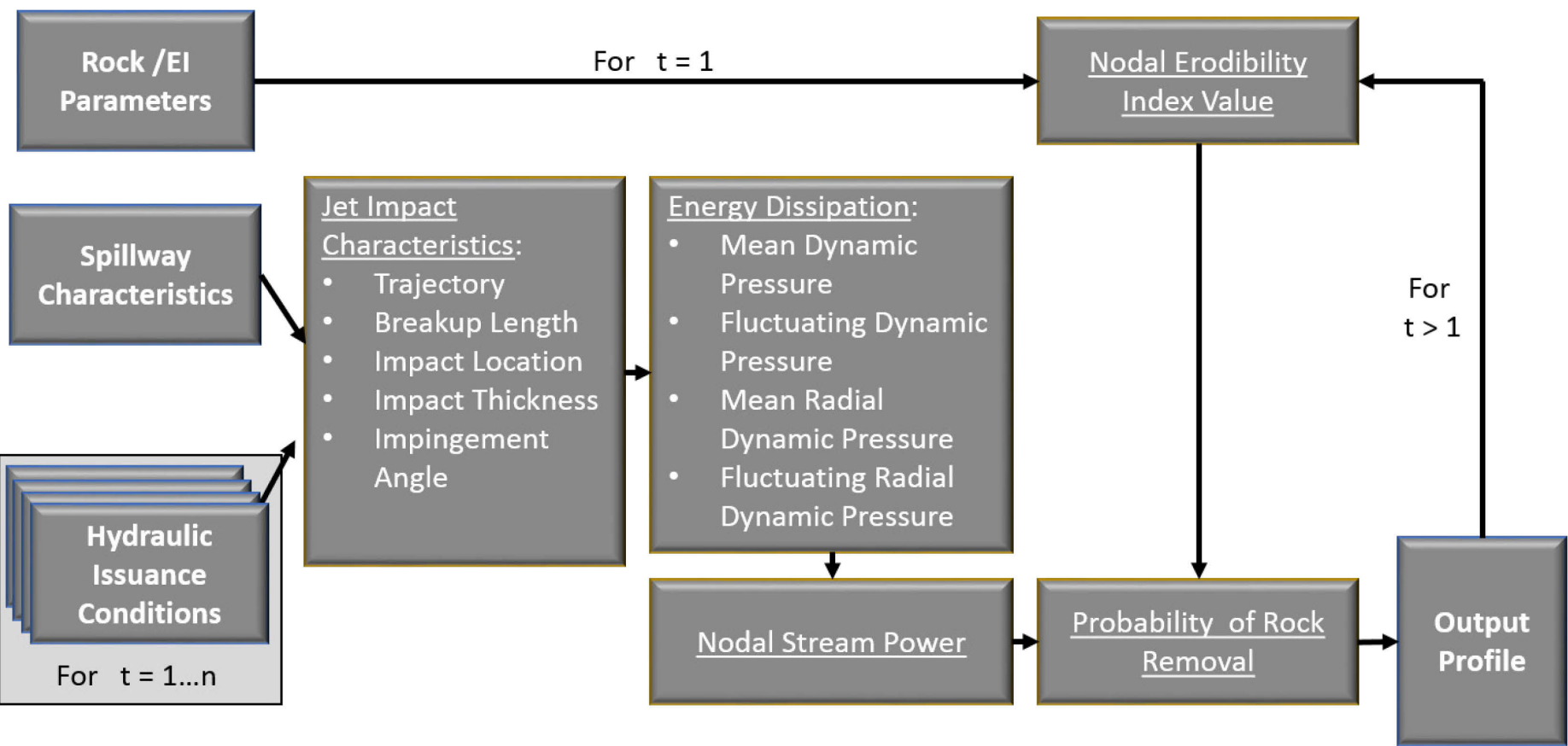

Figure 2. Numerical model workflow 
Once the jet is submerged, the four pressure coefficients identified by Castillo (2006, 2007) and Bollaert (2002) are combined with the stream power at impingement to calculate the total stream power, $\mathrm{P}_{\text {total }}$, for every defined unit area $(0.30 \mathrm{~m} \times 0.30 \mathrm{~m})$ within the plunge pool using Equation 4, modified from Annandale (2006). Here $p_{\text {jet }}$ is the calculated stream power at impingement with the plunge pool water surface, $\mathrm{Y}$ is any plunge pool depth, $\mathrm{B}_{\mathrm{j}}$ is the jet thickness at impingement, $r$ is any given distance from the jet centerline, and $r_{\max }$ is the maximum radial distance as defined by Bollaert (2002):

$$
\begin{aligned}
& P_{\text {total }}\left(Y / B_{j}, r / r_{\text {max }}\right)= \\
& p_{\text {jet }}\left[\left(C_{p}\left(Y / B_{j}\right) C_{p r} / C_{p}\left(r / r_{\max }\right)\right)+\right. \\
& \left.\left(C^{\prime}{ }_{p}\left(Y / B_{j}\right) C^{\prime}{ }_{p r} / C^{\prime}{ }_{p}\left(r / r_{\max }\right)\right)\right]
\end{aligned}
$$

The model compares corresponding EI values and total stream power values for each unit area of the profile to assess whether the erosive capacity of the plunging jet is sufficient to remove the portion of the rock mass at each location. The erosion threshold identified by Annandale in Figure 1 represents a solid boundary at which erosion initiates, however in reality the threshold is better represented by a region. The model, therefore, uses Wibowo et al's (2005) logistic regression, expressed in Equation 5, to assess the probability of scour based on the stream power experienced by the rock mass and the erosive resistance of the rock mass from Annandale's EIM. Here $\mathrm{P}(\mathrm{E})$ is the probability of scour, $\mathrm{K}$ is the EI val$\mathrm{ue}$, and $\mathrm{P}_{\text {total }}$ is the stream power experienced by the rock.

$$
P(E)=1 /\left(1+e^{-\left(-1.859-7.029 \ln K+9.798 \ln P_{\text {total }}\right)}\right)(5)
$$

Probability values range from 0.0 to 1.0 , with 0.0 representing a $0 \%$ likelihood of rock removal and 1.0 represented a $100 \%$ likelihood of rock removal. The rock mass at any location along the profile with a $\mathrm{P}(\mathrm{E}) \geq 0.50$ is assumed to be removed by the power of the jet. The EI profile within the model is then modified such that locations where the probability of removal meets or exceeds the 0.50 threshold are replaced with null values to signify their removal.

\subsection{Comparison of cumulative energy to scour depth}

The modeled scour depths and surveyed scour depths were compared to the total energy from stream power used to remove rock along the rockwater interface. Energy was summed over the period of record to generate cumulative energy (in mega joules). An additional comparison of the difference in surveyed versus modeled depth was also conducted. A total of 21 data points were included in the analysis, spread across four sections at the three dam sites. Each plunge pool survey provided a depth for comparison to the modeled results.

Goodness of fit was judged based on the Correlation Coefficient ( $\mathrm{R}^{2}$ value) and the Standard Error, based on the 21-point data set. A detailed analysis of the compared results is included in Rock (2015).

\section{RESULTS}

A summary of model results and plunge pool survey invert depths are provided in Table 1. Surveyed and modeled depths were taken as the deepest point along the profile location. Cumulative energy (in mega joules) is calculated as the integral, over time, of the product of stream power imparted to the rock mass that results in rock removal and the duration over which the rock is subjected to the stream power.

Plots of the surveyed depth, modeled depth, and difference between surveyed and modeled depth versus cumulative energy for the 'Mean' and 'High' erosive resistance cases and the associated best fit lines are provided in Figure 3. A quantitative assessment of the goodness of fit of each line of best fit is provided in Table 2 .

The results show the smallest difference between surveyed and modeled depth occurred at the Peace Canyon Dam site. The nature of the various geomechanical units and their distribution within the plunge pool at this site were better known as compared to the other two dam sites. The difference in surveyed and modeled depth at Seven Mile Dam was greater, but still a good fit based on the statistical analysis of the sites conducted in Rock (2015). The greater difference is likely due to the lack of information on the distribution of geomechanical units, even though abundant geologic information on the units was available. The W.A.C. Bennett Dam had a greater difference between surveyed and modeled depth, likely due to the more complex spillway geometry and associated hydraulic conditions.

\section{CONCLUSIONS}

The logarithmic nature of the cumulative energy versus the modeled depth, surveyed depth, and difference in depth indicates that the rate of scour decreases over time as each plunge pool develops. Due to this decrease higher magnitude discharge events are required to enact change within the plunge pool, based on data for the dam sites with flip bucket type energy dissipaters. This result is not unexpected and is observed not only in the modeled depths versus cumulative energy, but in the surveyed depths versus cumulative energy. In addition, the plot between depth difference and cumulative energy indicates greater variance between modeled and surveyed plunge pool depths with larger cumulative energy 
Table 1. Cumulative energy imparted to plunge pool by survey date

\begin{tabular}{|c|c|c|c|c|c|}
\hline & Survey Date & $\begin{array}{l}\text { Cumulative } \\
\text { Energy } \\
(\mathrm{MJ}) \\
\end{array}$ & $\begin{array}{l}\text { Surveyed Depth } \\
\text { (m) }\end{array}$ & $\begin{array}{l}\text { Modeled } \\
\text { Depth } \\
(\mathrm{m}) \\
\end{array}$ & $\begin{array}{l}\text { Modeled vs. Surveyed } \\
\text { Depth Difference* } \\
(\mathrm{m})\end{array}$ \\
\hline Peace & 10/30/1979 & - & - & - & - \\
\hline Canyon Dam & $4 / 15 / 1980$ & $9.27 \times 10^{7}$ & 12.2 & 11.3 & -0.9 \\
\hline \multirow{5}{*}{ Bays $3 \& 4$} & $9 / 5 / 1981$ & $2.80 \times 10^{8}$ & 12.2 & 11.3 & -0.9 \\
\hline & $10 / 1 / 1983$ & $4.48 \times 10^{8}$ & 12.2 & 11.3 & -0.9 \\
\hline & $10 / 8 / 1985$ & $4.86 \times 10^{8}$ & 12.2 & 11.3 & -0.9 \\
\hline & $8 / 4 / 1996$ & $2.72 \times 10^{9}$ & 12.2 & 14.0 & 1.8 \\
\hline & $6 / 12 / 2007$ & $3.38 \times 10^{9}$ & 13.1 & 14.0 & 0.9 \\
\hline \multirow{3}{*}{$\begin{array}{l}\text { Peace } \\
\text { Canyon Dam }\end{array}$} & $10 / 30 / 1979$ & - & - & - & - \\
\hline & $4 / 15 / 1980$ & $5.55 \times 10^{7}$ & 6.7 & 3.4 & -3.4 \\
\hline & $9 / 5 / 1981$ & $1.20 \times 10^{8}$ & 8.2 & 3.4 & -4.9 \\
\hline \multirow[t]{3}{*}{ Bays $5 \& 6$} & $10 / 1 / 1983$ & $2.13 \times 10^{8}$ & 8.2 & 3.4 & -4.9 \\
\hline & $8 / 4 / 1996$ & $9.04 \times 10^{8}$ & 8.2 & 5.2 & -3.0 \\
\hline & $6 / 12 / 2007$ & $1.06 \times 10^{9}$ & 8.2 & 6.1 & -2.1 \\
\hline \multirow[t]{2}{*}{ Seven Mile Dam } & $10 / 30 / 1979$ & - & - & - & - \\
\hline & $12 / 14 / 1979$ & $7.33 \times 10^{8}$ & 7.3 & 11.6 & 4.3 \\
\hline \multirow[t]{6}{*}{ Bays $1 \& 2$} & $8 / 1982$ & $8.11 \times 10^{9}$ & 14.9 & 27.1 & 12.2 \\
\hline & $9 / 20 / 1984$ & $1.09 \times 10^{10}$ & 14.9 & 27.1 & 12.2 \\
\hline & $10 / 15 / 1986$ & $1.27 \times 10^{10}$ & 14.9 & 27.1 & 12.2 \\
\hline & $10 / 1 / 1988$ & $1.28 \times 10^{10}$ & 15.8 & 27.1 & 11.3 \\
\hline & $11 / 18 / 1997$ & $2.68 \times 10^{10}$ & 15.8 & 27.1 & 11.3 \\
\hline & $12 / 9 / 2011$ & $3.76 \times 10^{10}$ & 15.8 & 27.1 & 11.3 \\
\hline \multirow[t]{4}{*}{ W.A.C. Bennett Dam } & $6 / 13 / 1972$ & - & - & - & - \\
\hline & $5 / 19 / 1973$ & $1.06 \times 10^{10}$ & 27.7 & 38.4 & 10.7 \\
\hline & $8 / 4 / 1996$ & $3.37 \times 10^{10}$ & 32.0 & 38.4 & 6.4 \\
\hline & $10 / 1 / 2002$ & $3.69 \times 10^{10}$ & 32.0 & 38.4 & 6.4 \\
\hline
\end{tabular}

* Depth difference indicative of modeled versus surveyed plunge pool depth; positive values indicate deeper modeled scour as compared to surveyed scour; negative values indicate shallower modeled scour as compared to surveyed scour.

inputs; as more energy is absorbed within the plunge pool and underlying rock material, more uncertainty exists within the model. It is encouraging that the difference in modeled and surveyed plunge pool depth is highly correlated and exhibits a low standard error estimate

Table 2. Cumulative energy goodness of fit statistics

\begin{tabular}{|lcc|}
\hline $\begin{array}{l}\text { Cumulative Energy } \\
\text { vs. }\end{array}$ & $\mathrm{R}^{2}$ & $\begin{array}{c}\text { Standard Error* } \\
(\mathrm{m})\end{array}$ \\
\hline Depth Difference & 0.91 & 2.0 \\
\hline Surveyed Depth & 0.53 & 5.2 \\
\hline Modeled Depth & 0.90 & 3.9 \\
\hline
\end{tabular}

$* \mathrm{R}^{2}$ and standard error values correspond to best fit equations provided in figure 3 .

The comparison between the various depth parameters and cumulative energy introduces a temporal aspect to the analysis. The temporal distribution of the discharge events plays an important role in plunge pool development and merits further study.
Scour rate and cumulative energy merit further research to assess the strength, significance, and implications of the relationship between the two.

\section{REFERENCES}

Annandale, G.W. 1995. Erodibility. Journal of Hydraulic Research 33(4):471-494.

Annandale, G.W. 2006. Scour Technology; Mechanics and Engineering in Practice. McGraw-Hill Book Company, New York, NY.

Bollaert, E.F.R. 2002. Transient water pressures in joints and formation of rock scour due to high-velocity jet impact [PhD Thesis]: Laboratory of Hydraulic Constructions, Ecole Polytechnique Federale de Lausanne, Switzerland.

Bureau of Reclamation, PROFILE: Water Surface Profile Program for Prismatic Channels Version 1.10: US Bureau of Reclamation, U.S. Department of the Interior, US Bureau of Reclamation, Engineering Monograph No. 42, 1990.

Castillo, L.G. 2006. Aerated jets and pressure fluctuations in plunge pools, in Proceedings, International Conference on HydroScience and Engineering, 7th, Philadelphia: Pennsylvania, US. 


\section{Cumulative Energy vs. Difference in Depth}

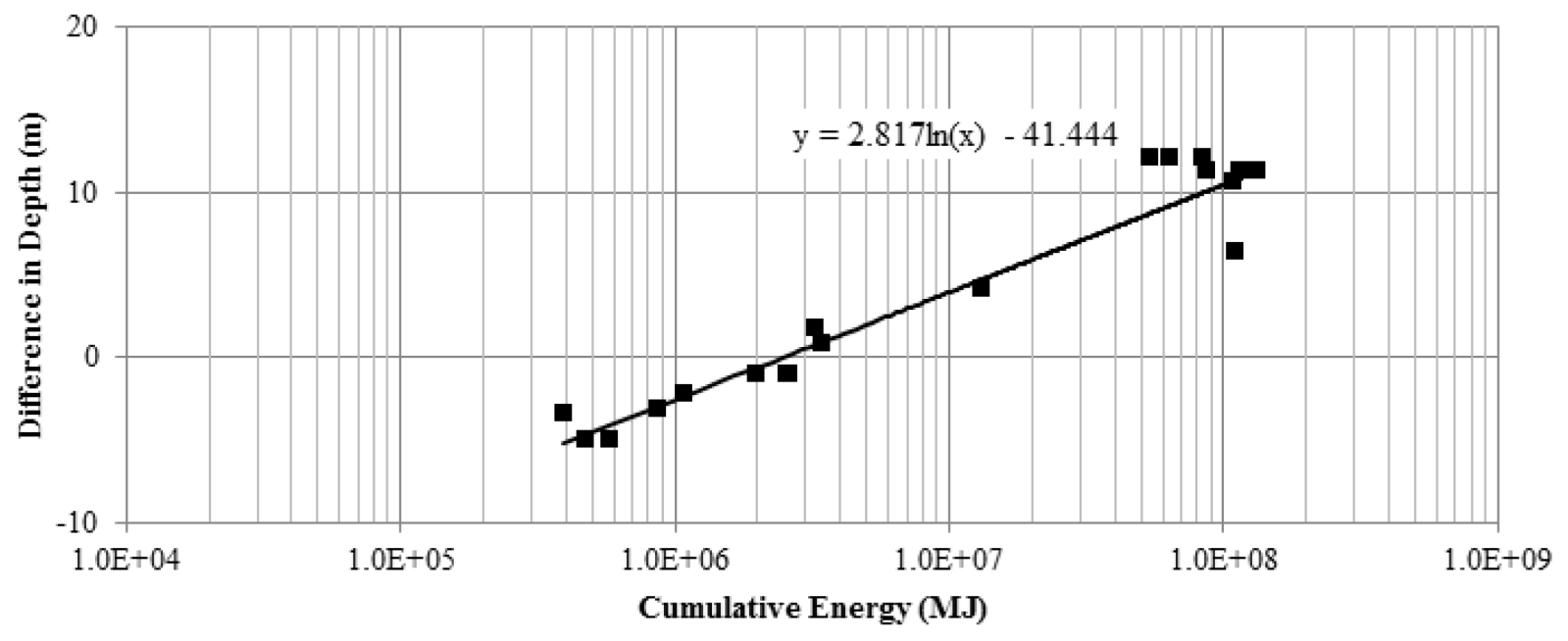

Cumulative Energy vs. Survey Depth

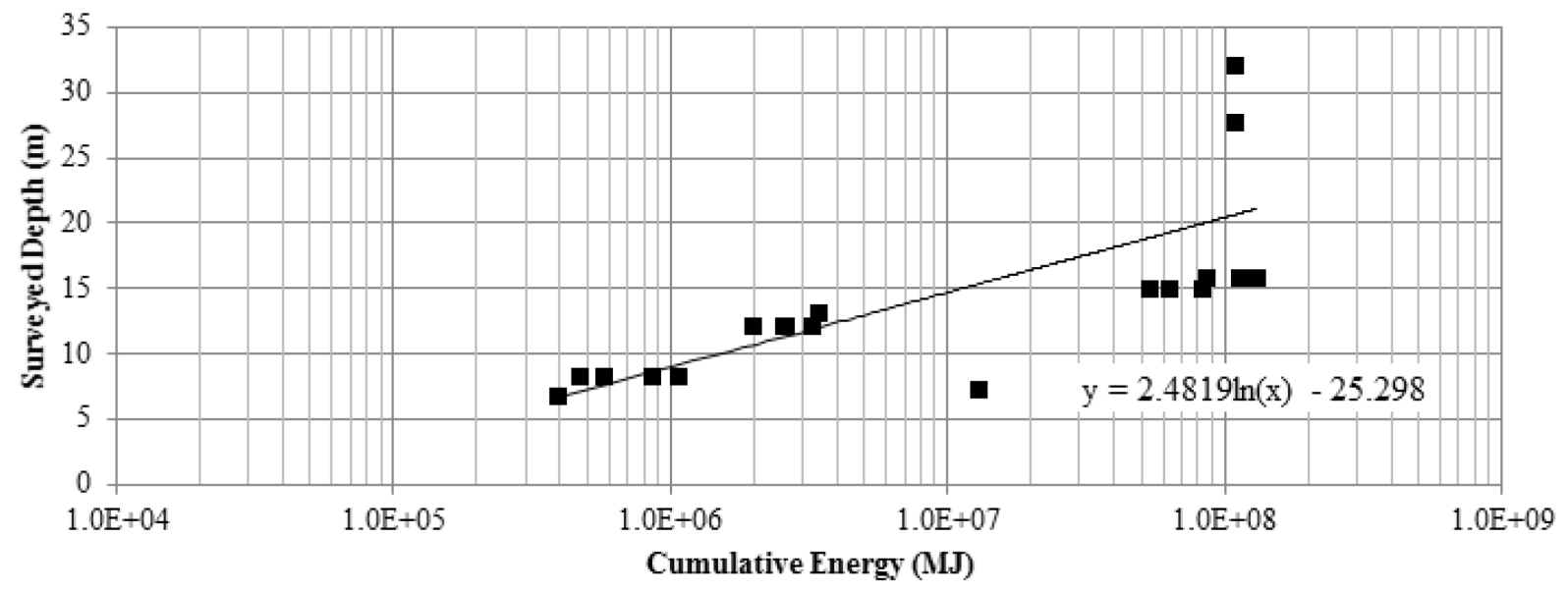

Cumulative Energy vs. Modeled Depth

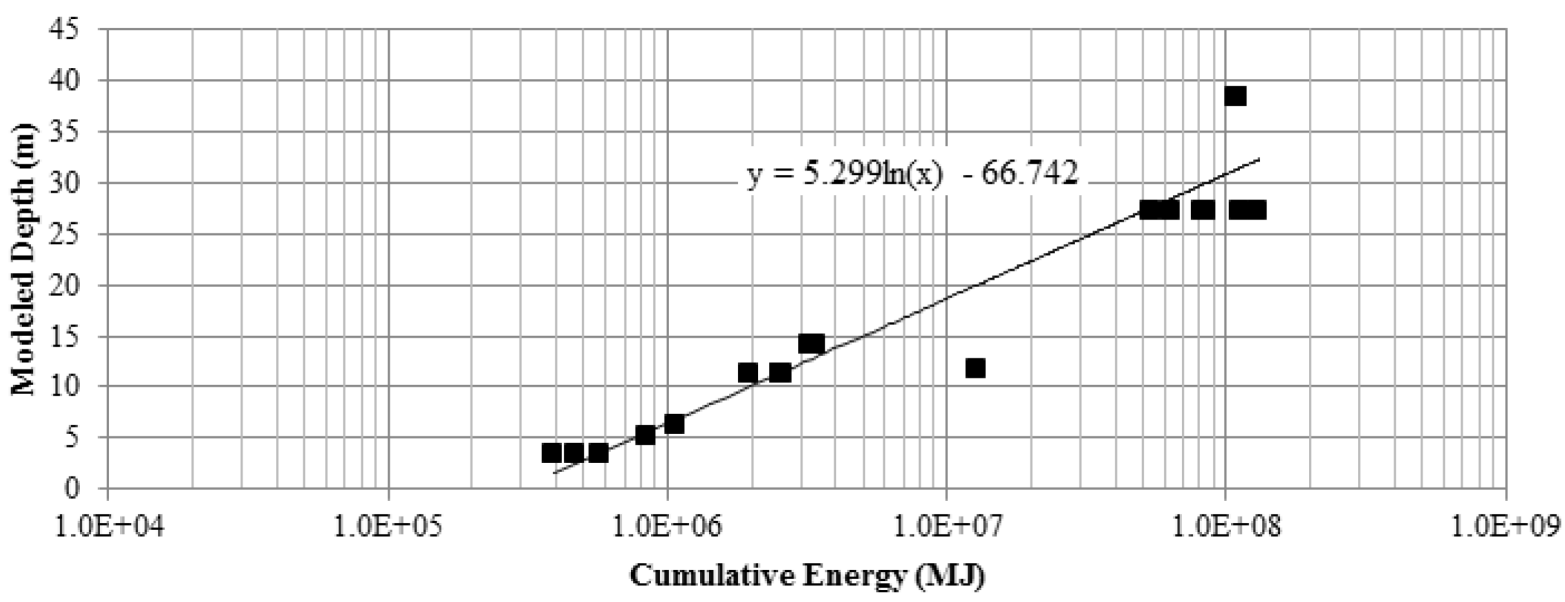

Figure 3. Cumulative energy vs. differences between surveyed and modeled depth (in meters) 
Castillo, L.G. 2007. Pressures characterization of undeveloped and developed jets in shallow and deep pool, in Proceedings, International Association of Hydraulic Engineering and Research, 32nd Congress, Venice, Italy.

Ervine, D.A., \& Falvey, H.T. 1987. Behavior of turbulent jets in the atmosphere and in plunge pools, in Proceedings of the Institution of Civil Engineers 2(83): 295.

Ervine, D.A.; Falvey, H.T.; \& Withers, W. 1997. Pressure fluctuations on plunge pool floors. Journal of Hydraulic Research 35: 295-314.

Falvey, H.T. 1990. Cavitation in chutes and spillways. Engineering Monograph No. 42, US Bureau of Reclamation.

Henderson, F.M. 1966. Open Channel Flow. MacMillan, New York, NY.

Pfister, M., Hager, W.H., \& Boes, R.M. 2014. Trajectories and air flow features of ski jump-generated jets. Journal of $\mathrm{Hy}$ draulic Research 52(3):336-346.

Rock, A.J. 2015. A Semi-Empirical Assessment of Plunge Pool Scour: Two-Dimensional Application of Annandale's Erodibility Index Method on Four Dams in British Columbia, Canada: Unpublished M.S. Thesis, Department of Geological Engineering, Colorado School of Mines, Golden, CO.

Wibowo, J.L., Yule, D.E., \& E. Villanueva, Earth and Rock Surface Spillway Erosion Risk Assessment, Alaska Rocks 2005, 40th U.S. Symposium on Rock Mechanics, American Rock Mechanics Association, Anchorage, AK. 